un mercado. Se debe esto a que dos palabras árabes diferentes se transformaron en una misma española. Así, el origen de la primera acepción es azaue y el de la segunda azoe. A lo que parece, ya "azogue» no se usa con este último significado. En cuanto al árabe azaue, se ha transformado o ha desaparecido: el mercurio es llamado actualmente zaibac.

*Alhaja» viene de $a l-h a y a$, pero ahora se dice $a l-h i l a$.

Pero no sólo ha tenido el árabe cambios formales desde la dominación de los muslimes en España; también las palabras han variado de significado. Así ya no se llama alcuza al depósito del aceite en la mesa, sino a un jarro para tener agua en el comedor. Idioma vivo, ha tenido que evolucionar, por lo que muchas de aquellas palabras que dieron vida a la cuarta parte de la lengua española son ya para los árabes actuales letra muerta.

El árabe se habla actualmente en Arabia propiamente dicha, en Mesopotamia, en Palestina, en Siria, en Monte Líbano, en Egipto, en Tripolitania, en Argelia, en Túnez, en Marruecos y en varias tribus nómades al sur de estos cuatro ultimos países. - J A N U A R I O E S P I N OSA.

\title{
EL CONDE KEYSERLING EN LA SORBONA
}

aOS lucidos viajeros que regresan de la patria de Lincoln se hallan en general de acuerdo sobre un punto básico de sus conclusiones, hasta cuando sus reservas de detalle difieren'radicalmente. Fstán unánimes en proclamar que los Estados Unidos representan en su relación con Europa una nueva civilización, un mundo distinto.

Para el conde Keyserling, "el mago que aspira a renovar a hombres y pueblos»-según el donoso decir de Francisco García Calderón-, la joven Democracia del Norte podía ser considerada todavía antes de la guerra, a despecho de su independencia política, como una prolongación colonial del Viejo Continente. En 1916, durante el período que precede a la intervención de Estados Unidos en el conflicto armado, las cosas cambian y una nueva era se abre para la gran República. Los descendientes de las trece colonias inglesas toman conciencia de sus fuerzas magníficas, de la cabal pujanza que ellos significan en presencia de una Europa envejecida y des- 
garrada por absurdas disputas... Se forma lo que se pudiera llamar una nación norteamericana.

El nuevo Estado evoluciona rápidamente $y$, a medida que la transformación se opera, divergencias cada vez más hondas se multiplican entre la madre Europa y la hija de ultramar.

En una brillante y amable exposición desarrollada en la Sorbona en el pasado mes de Junio, bajo los auspicios del Foyer de la Nouvelle Europe, el conde Keyserling señal6 a su auditorio (aunque reservándose para más tarde el capítulo de sus conclusiones definitivas y completas), la prodigiosa distancia que separa hoy sin excepción a los países de la cultura clásica de los Estados Unidos de América.

No se trata de establecer paralelos o comparaciones cualitativas que en esta ocasión no vienen al caso. Que los angloamericanos se crean el pueblo más dinámico, más adelantado, más progresista de la tierra; que los europeos pretendan, por su lado, que toda civilización procede de ellos y que no es dable aun referirse a las virtudes castizas de una nación moza, todo esto tiene una importancia muy relativa. $\mathrm{Si}$ seguimos al maestro de Darmstadt en sus perentorias sentencias, dos países son en el universo moderno los que poseen más alta significación, a pesar de las inferioridades morales o culturales que puedan atribuírseles con respecto a la Furopa desvaída: Estados. Unidos en un polo y la Rusia bolchevique en el otro opuesto.

Fl porvenir se elabora a través de esos dos pueblos, gracias a ellos, acaso contra la voluntad de ellos mismos... Así como en la segunda centuria de nuestra era-y a pesar del aparente esplendor del Imperio romano-, los destinos del mundo se preparan en las lóbregas catacumbas cristianas que, como es bien sabido, no encarnaban ni la élite social ni la refinada cultura de la época.

Numerosos ejemplos podrían recordarse para fijar la diferencia total que existe entre la civilización angloamericana y la europea. La falta de espacio nos obliga a citar nada más que tres:

1. Ante todo, y no obstante el descrédito que ha sufrido la noción de la majestad dek Estado en el curso de las últimas décadas, sigue predominando todavía aquella norma en las mentalidades del Antiguo Continente. Inclusive también en las directivas socialistas que buscan ampararse en el poder (o sea en el Estado) para aumentar la fuerza de éste y multiplicar sus atribuciones. En Norte-América no tiene ningún prestigio. El Estado es una máquina organizada para rendir 
determinados servicios (que rinde bien o mal), pero enfrente del que sería absurdo postrarse y ante el cual nadie se somete sino en la exacta medida que el interés privado aconseja hacerlo.

En Estados Unidos no existe el respeto por la cosa pública tal como se cultiva en Europa. Los organismos privados ejercen dominio sobre la política, profesión ésta considerada como "oficio sin gloria». El "forum», cuya imagen continúa reflejándose en los parlamentos del Viejo Mundo, carece de magnificencia. Engañar al Estado no es tan sólo adorno de malandrines, y los norteamericanos aportan a este juego «deportivo» el mejor entusiasmo de su sangre joven...

2. Se afirma, a menudo, que los. Estados Unidos son un pueblo alejado en millares de leguas del socialismo. Pero, explica el conde Keyserling, si se liberta la idea matriz del socialismo de cierta interpretación marxista, socialismo quiere decir en su esencia primacía de lo colectivo sobre lo individual. La fórmula yanqui es exactamente la misma. Los ciudadanos de Nueva York y de California no hablan de socialismo porque viven en realidad en un país socializado, en un marco inmenso donde se obra por masas, donde se piensa colectivamente, donde se viste en serie, donde se goza con placer estandardizado .. Nada-exclama el autor de El Minndo que Niace, acaso con una brizna de exageración,

nada es menos original que un americaro, poco importa que pertenezca o no a la casta de los inteligentes. Ningún pueblo-agrega el filósofo-se halla desprovisto a tal extremo de imaginación como el de Estados Unidos.

3. En fin, el tercer punto es la importancia especial que tiene la mujer en Norte-América. Como los hombres están absorbidos desde la juventud y antes de la mayoría de edad por la obligación de ganar el pan, de hacer dinero, el sexo débil ha sido el primero, y durante largo tiempo casi el único, en poseer algunos rudimentos de lo que los europeos denominan cultura. El hombre está por lo general demasiado ocupado para discurrir, o por lo menos, para raciocinar gratuitamentc, es decir, para pensar en disciplinas ajenas a la actividad propia en que se encuentra empeñado.

Las mujeres, pues, han tomado ventaja preponderante; son ellas las irspiradoras de tan gran número de leyes puritanas, y esta influencia explicaría, según el pensador teutón, ciertas concepciones específicamente americanas, «tan estrechas, tan escasas de genio, tan singulares, que a los europeos se les antojan casi incomprensibles». La ley de prohibición y la manera brutal y absoluta como ella fué concebida, procederían, 
de esta suerte, de una idea femenina. Otra idea (femenina) del mismo orden es la de que Norte-América debe constituir un mundo cerrado, bastándose a sí mismo y lo menos obligada posible en los múltipless problemas del universo actual. Concepción poco conciliable con la importancia geográfica de NorteAmérica, con su colosal riqueza, con la pretensión que abriga la Democracia del Norte de ser "la palanca y el guía moral del resto de la humanidad».

Es preciso admitir el hecho americano, concluye el huésped de la Sorbona. Pero ante esta realidad formidable, Europa no puede vivir sino manteniendo el sentido que ella tiene de la variedad, de la diferencia y, para decirlo todo de una vez, de la individualidad. Asistimos al nacimiento de un Mundo Nuevo, y éste tendrá la significación que le asignen los espíritus de élite capaces de comprenderlo. Fn este mundo de masas, Europa, cogida entre dos fuegos: el materialismo práctico de América y el materialismo doctrinal de Rusia (que podría muy bien ser mañana el de toda Asia), sólo podrá subsistir conservando el espíritu, sosteniendo o recreando los valores espirituales de que tanta necesidad tiene el universo contemporáneo.

Sin embargo, el espíritu nunca ha sido colectivo; el espíritu es siempre privilegio del individuo. Renunciando a querellas. sin objeto, cuya prolongación le acarrearía una definitiva caducidad, Europa debe mantener en su propio seno las robustas individualidades nacionales que necesita para la germinación de pensadores abundantes y originales. He ahí su verdadera riqueza. Es la sola cosa útil que podrá brindarle al Continente abrumado de bienes terrenos. Furopa, en reacción contra el doble materialismo que la cerca, puede salvarse aún si permanece. siendo la sal de la tierra, el fermento espiritual del mundo.-CARLOS DEAMBROSIS MARTINS.

Exclusivo para Atenea en Chile.

\section{DIVAGACIONES ALREDEDOR DE LA POESIA}

\section{V.-LA POEsÍA DE HOY}

(G)

ADA escuela literaria nueva obedece a un deseo de originalidad, que es la distintiva de la alta literatura. Cuando una escuela agota los materiales que constituyeron su riqueza o su aporte a la literatura, materiales de que se extrajeron infinitos matices, tantos casi como escritores los explotaron, sur 